ISSN 1678-3921

Journal homepage: www.embrapa.br/pab

For manuscript submission and journal contents, access: www.scielo.br/pab

\section{Geographical distribution of the incubation period of coffee leaf rust in climate change scenarios}

\begin{abstract}
The objective of this work was to simulate the geographical distribution of the incubation period of coffee leaf rust in Coffea arabica, using data of two regional climate models, Eta-HadGEM2-ES and EtaMIROC5. The scenario of high greenhouse gas emission (RCP $\left.8.5 \mathrm{~W} \mathrm{~m}^{-2}\right)$ was used for the states of Minas Gerais and São Paulo, Brazil, for current and future climate scenarios. The behavior of six different regression equations for incubation period (IP), available in the literature, was also analyzed as affected by data from the regional climate models. The results indicate the possibility of an increase in the affected area in the studied region, when the IP is less than 19 days, from $0.5 \%$ for Eta-MIROC5 to $14.2 \%$ for EtaHadGEM2-ES. The severity of coffee leaf rust in future scenarios should increase in the hottest and wettest months of the year, extending to the driest and coldest months. The potential of rust infection is estimated differently by the studied equations. In higher temperature scenarios, the Kushalappa \& Martins equation indicates a very high severity potential.
\end{abstract}

Index terms: Coffea arabica, Hemileia vastatrix, Arabica coffee, plant disease severity, regional climate modelling, spatial analyses.

\section{Distribuição geográfica do período de incubação da ferrugem do cafeeiro em cenários de mudanças climáticas}

Resumo - O objetivo deste trabalho foi simular a distribuição geográfica do período de incubação da ferrugem do cafeeiro Coffea arabica, com uso de dados de dois modelos climáticos regionais, o Eta-HadGEM2-ES e o EtaMIROC5. O cenário de alta emissão de gases de efeito estufa (RCP $\left.8,5 \mathrm{~W} \mathrm{~m}^{-2}\right)$ foi utilizado para os estados de Minas Gerais e São Paulo, para os cenários climáticos atual e futuro. O comportamento de seis diferentes equações de regressão do período de incubação (PI), disponíveis na literatura, também foi analisado em função dos dados dos modelos climáticos regionais. Os resultados indicam possibilidade de aumento de área afetada na região estudada, com PI inferior a 19 dias, de $0,5 \%$ para Eta-MIROC5 a 14,2\% para Eta-HadGEM2-ES. A severidade da ferrugem do cafeeiro em cenários futuros deverá aumentar nos meses mais quentes e úmidos do ano, estendendo-se para os meses mais secos e frios. O potencial de infecção da ferrugem é estimado de forma diferente pelas equações estudadas. Em cenários de temperaturas mais elevadas, a equação de Kushalappa \& Martins indica um potencial muito alto de severidade.

Termos para indexação: Coffea arabica, Hemileia vastatrix, café arábica, severidade da doença, modelos climáticos regionais, análises espaciais. 


\section{Introduction}

Since the 2000s, studies have shown that coffee cultivation could be negatively impacted by scenarios of possible climate change. The first of these researches performed in Brazil mainly addressed the loss of area suitable for planting due to the rise of the average global temperature (Assad et al., 2004; Zullo Junior et al., 2006). Other works published in the country (Ghini et al., 2008) and in other coffee production areas, as Mexico (Gay et al., 2006), Colombia, and Africa (Jaramillo et al., 2011), have also focused on other themes, such as the adaptation of coffee to climate change scenarios and the relationship of the species with pests and diseases. Therefore, besides pointing out the loss of traditional cultivation (Assad et al., 2004; Zullo Junior et al., 2006; Zullo Jr. et al., 2011; Ovalle-Rivera et al., 2015; Tavares et al., 2017) and production (Villers et al., 2009) areas, these scientific studies have alerted to the important impact of the incidence of coffee diseases, considering modifications in their pattern, severity (Chakraborty et al., 2000), intensity (Jaramillo et al., 2011), cycle, and geographical distribution (Ghini et al., 2011a).

Among the diseases with great economic importance, coffee leaf rust (Hemileia vastatrix Berk. $\& \mathrm{Br}$.) stands out in the worldwide scenario, where the largest epidemics were driven by the combination of economic and meteorological causes (Avelino et al., 2015). In Brazil, coffee leaf rust is also an important disease (Zambolim, 2016), particularly in years of high fruit loading (López-Bravo et al., 2012; Zambolim, 2016). Although apparently already controlled by management practices, coffee leaf rust can still cause losses ranging from 30 to $50 \%$ of total production, which may reach up to $90 \%$ in large epidemics (Zambolim, 2016; Patrício, 2017), showing the devastating power of the disease (Avelino et al., 2015).

Coffee leaf rust epidemics in Brazil have a standard temporal cycle, starting in December, when rainfall and temperature increase (Zambolim, 2016). The disease can infect coffee plants at temperatures between 12.5 and $32^{\circ} \mathrm{C}$ (Zambolim, 2016), and its peak occurs in May and June (Patrício, 2017). Zambolim (2016) pointed out that the initial amount of coffee leaf rust inoculum depends on the weather conditions in winter, which, if hotter and rainier than the normal climate pattern, result in a greater amount of inoculum at the beginning of the disease cycle in coffee plantations.
The growth rate of the disease (Zambolim, 2016) can be determined based on the number of days from the penetration of coffee leaf rust via stomata on the underside of coffee leaves to the expression of disease symptoms in the plant, known as incubation period (IP) (Patrício, 2017). Since temperature is one of the main variables of that equation, the IP has been used to estimate the probability of the occurrence of coffee leaf rust in different climate scenarios (Hamada et al., 2006; Ghini et al., 2008; Meira et al., 2009; Hamada et al., 2011). The shorter the IP, the greater the number of generations of the pathogen and, therefore, the higher the disease growth rate (Patrício, 2017).

In the literature, there are some ten equations that estimate the IP of coffee leaf rust, developed for different cropping systems and soil and edaphoclimatic conditions. Traditionally, most of the studies on the estimation of the IP of coffee leaf rust in Brazil adopt the equation proposed by Moraes et al. (1976). However, in scenarios of possible changes in the normal climate pattern, the evaluation of different IP equations is important for a better understanding of the variation in the disease growth rate in different climate patterns.

Changes in coffee leaf rust growth rates related to climate, however, are not simple to determine. Consequently, designing how the disease will behave under climate conditions different from the current one is also not a trivial task. A method widely used, when global climate models were first published and disseminated by Intergovernmental Panel on Climate Change (IPCC), were the climate scenario projections combined with the IP equation by Moraes et al. (1976), as performed by Hamada et al. (2006, 2011) and Ghini et al. (2008). However, with the evolution of the science of climate modelling, it has been found that global models have a very limited spatial scale, varying from 100 to $200 \mathrm{~km}$, and, therefore, do not adequately capture local characteristics (Tavares et al., 2017), which are highly important for the development of the disease (Seem, 2004). The downscaling process of global climate models results in regional climate models (RCMs), which present a more refined spatial resolution, being more adequate in the evaluation of the relationships between the disease and the regional environment. However, even with this evolution, it is worth emphasizing that few studies have been

Pesq. agropec. bras., Brasília, v.54, e00273, 2019

DOI: 10.1590/S1678-3921.pab2019.v54.00273 
performed on coffee leaf rust and regional climate change models in Brazil.

The objective of this work was to simulate the geographical distribution of the incubation period of coffee leaf rust in Coffea arabica, using data of two regional climate models, Eta-HadGEM2-ES and EtaMIROC5.

\section{Materials and Methods}

The study was carried out in states of São Paulo and Minas Gerais, Brazil, which are traditional areas for the cultivation of the Coffea arabica species in the country. São Paulo is located between the $54^{\circ} 00^{\prime}$ and $43^{\circ} 30^{\prime} \mathrm{W}$ longitudes and $25^{\circ} 30^{\prime}$ and $19^{\circ} 30^{\prime} \mathrm{S}$ latitudes, with altitudes ranging between 300 and $900 \mathrm{~m}$. According to Köppen-Geiger's classification, the state comprises five climate groups: $\mathrm{Cfa}, \mathrm{Aw}, \mathrm{Cfb}, \mathrm{Af}$, and Am. Minas Gerais is situated between the $51^{\circ} 30^{\prime}$ and $39^{\circ} 30^{\prime} \mathrm{W}$ longitudes and the $23^{\circ} 00^{\prime}$ and $14^{\circ} 00^{\prime} \mathrm{S}$ latitudes, with 100 to $1,500 \mathrm{~m}$ altitude. The prevalent type of climate is Aw, but Cfa, Cfb, Cwa, and Cwb also occur. The region offers favorable climatic conditions for coffee growing, with dry and cold winters, high thermal amplitudes, and hot and humid summers.

The IP of coffee leaf rust was estimated with data from six regression equations, covering full-sun and shaded cultivation systems, described as follows. Equation 1: $\mathrm{Y}=90.61-0.408 \mathrm{X}_{1}-0.440 \mathrm{X}_{2}$ (Rayner, 1961), where $\mathrm{Y}$ is the number of days to start sporulation in $50 \%$ of the lesions; $X_{1}$ is the maximum average temperature, in degrees Fahrenheit; and $\mathrm{X}_{2}$ is the minimum average temperature, also in degrees Fahrenheit. Equation 2: $\mathrm{Y}=63.47$ - 1.526X (Ortolani et al., 1971), where $\mathrm{Y}$ is the IP estimate, in days; and $\mathrm{X}$ is the average temperature, in Celsius. Equation 3: $\mathrm{Y}=103.01-0.98 \mathrm{X}_{1}-2.10 \mathrm{X}_{2}$ (Moraes et al., 1976), in full-sun and shaded coffee cultivation conditions, where $\mathrm{Y}$ is the IP estimate, in days; $X_{1}$ is the maximum average temperature, in Celsius; and $\mathrm{X}_{2}$ is the minimum average temperature, also in Celsius. Equation 4: $\mathrm{Y}=93.27-0.99 \mathrm{X}_{1}-1.51 \mathrm{X}_{2}$ (Moraes et al., 1976), in a full-sun cultivation condition, where $\mathrm{Y}$ is the IP estimate, in days; $\mathrm{X}_{1}$ is the maximum average temperature, in Celsius; and $\mathrm{X}_{2}$ is the minimum average temperature, also in Celsius. Equation 5: $\mathrm{Y}=113.92-1.02 \mathrm{X}_{1}-2.69 \mathrm{X}_{2}$ (Moraes et al., 1976), in a shaded cultivation condition, where $Y$ is the IP estimate, in days; $\mathrm{X}_{1}$ is the maximum average temperature, in Celsius; and $\mathrm{X}_{2}$ is the minimum average temperature, also in Celsius. Equation 6: $\mathrm{Y}=00.894-0.088 \mathrm{X}_{1}-4.084 \mathrm{X}_{2}$ (Kushalappa \& Martins, 1980), for macroclimate conditions, where $Y$ is the IP estimate, in days; $X_{1}$ is the maximum temperature, in Celsius; and $\mathrm{X}_{2}$ is the minimum temperature, also in Celsius.

Maps were generated for two chronological time periods: "current" scenario, climate normal of the models from 1961 to 1990; and "future" scenario, climate normal of the models from 2011 to 2040.

Two regional climate models were used to generate these maps: Eta-HadGEM2-ES and Eta-MIROC5. These models are downscaling versions, respectively, of the Hadley Centre Global Environment Model version 2 (HadGEM2), developed by Met Office Hadley Centre of the United Kingdom, and the Model for Interdisciplinary Research on Climate version 5 (MIROC 5), developed by Center for Climate Systems Research at University of Tokyo and National Institute for Environmental Studies at Japan Agency for Marine-Earth Science and Technology. The global models were detailed using the Eta Regional Climate Model (Chou et al., 2014).

To characterize the current and future scenarios, according to the projections of Global Climate Models, a high emission condition was adopted, i.e., the pessimistic scenario with representative concentration pathway (RCP) $8.5 \mathrm{~W} \mathrm{~m}^{-2}$, which is closer to the current $\mathrm{CO}_{2}$ emission conditions (Friedlingstein et al., 2014; Raupach et al., 2014). The RCP 8.5 scenario predicts that the terrestrial system will store $8.5 \mathrm{~W} \mathrm{~m}^{-2}$ emissions, with an increase in terrestrial temperature ranging from 2.6 to $4.8^{\circ} \mathrm{C}$.

Maximum, minimum, and average temperature variables were used for the generation of the IPs and spatialization of the current and future data from Eta-HadGEM2-ES and Eta-MIROC5. All the data from these models were made available by Instituto Nacional de Pesquisas Espaciais.

The output temperature data from the evaluated models were spatialized and interpolated by the inverse method of the distance square. Then, IP maps were generated for each month of the year for the current and future scenarios using Equations 1 to 6 .

The potential for coffee leaf rust infection is commonly assessed by the model proposed by Wallis (1970), which considers three degrees of disease 
severity according to IP. However, for a more detailed evaluation of the climate variations predicted by the different models in the different scenarios, the present study proposed a new scale of degree of severity, in which the classes originally proposed by Wallis (1970) were subdivided, totalizing six new ones (Table 1).

For each generated map, graphs were also elaborated considering the percentage of the study area in each of the disease severity classes, which allowed evaluating differences between equations.

Table 1. Classes of degree of severity and infection potential of coffee leaf rust (Hemileia vastatrix) in relation to the duration of the incubation period of the disease in Arabica coffee (Coffea arabica), in the states of Minas Gerais and São Paulo, Brazil.

\begin{tabular}{lcc}
\hline Class number & Incubation period (days) & Infection potential \\
\hline 1 & Shorter than or equal to 19 & Very high \\
2 & 20 to 29 & High \\
3 & 30 to 39 & Medium \\
4 & 40 to 49 & Low \\
5 & 50 to 59 & Very low \\
6 & Longer than 60 & Null \\
\hline
\end{tabular}

A

Eta-HadGEM2-ES

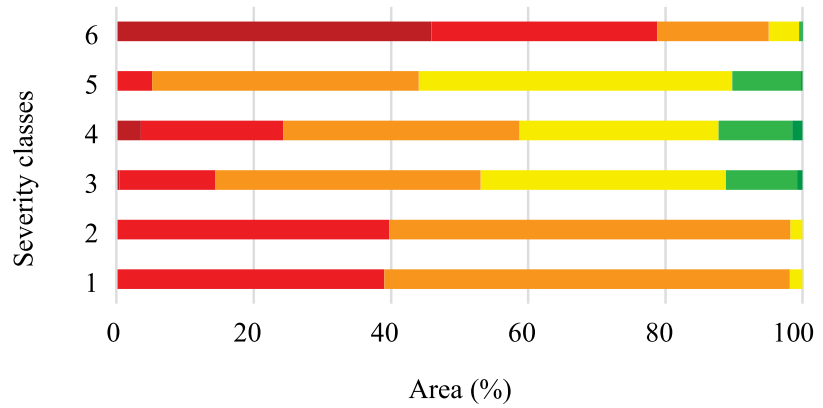

To analyze the data generated by each equation, in each model and scenario, the data were initially separated by equation, model, chronological time (current and future scenarios), severity class, month, number of points in each class, and percentage of area. Then, graphs were generated, allowing the temporal analysis.

The IP equations were studied jointly in order to analyze the behavior of the degree of coffee leaf rust severity in the future scenarios of the Eta-HadGEM2ES and Eta-MIROC5 models.

\section{Results and Discussion}

Equations 1 and 2 show similarities between rust severity classes in the evaluated models (Figure 1). In Eta-HadGEM2-ES, both equations indicate that 39\% of the affected area is in the high severity class and $58.5-59.0 \%$ in the medium one. The very high, low, very low, and null classes represent less than $2 \%$ of the total area. In Eta-MIROC5, the medium class was more prominent, with approximately $87 \%$ of the study area affected according to both equations. The other severity classes totaled less than $10 \%$ of the area.

B

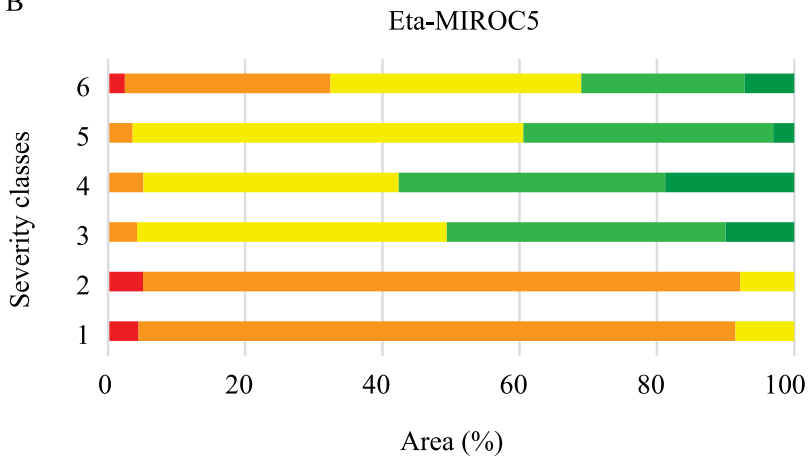

$$
\begin{array}{llllll}
1(\mathrm{VH}) & \mathbf{2}(\mathrm{H}) & \mathbf{3}(\mathrm{M}) & 4(\mathrm{~L}) & \mathbf{5}(\mathrm{VL}) & \mathbf{6}
\end{array}
$$

Figure 1. Area ( $\mathrm{X}$ axis), according to the six used equations ( $\mathrm{Y}$ axis), for the six severity classes of coffee leaf rust (Hemileia vastatrix) in Arabica coffee (Coffea arabica) in the states of Minas Gerais and São Paulo, Brazil, obtained by the EtaHadGEM2-ES (A) and Eta-MIROC5 (B) regional climate models for the current scenario from 1961-1990. Severity classes: 1(VH), very high; 2(H), high; 3(M), medium; 4(L), low; 5(VL), very low; and 6(N), null. Equation 1: $\mathrm{Y}=90.61-0.408 \mathrm{X}_{1}$ 0.440X $\mathrm{X}_{2}$; Equation 2: $\mathrm{Y}=63.47-1.526 \mathrm{X}$; Equation 3: $\mathrm{Y}=103.01-0.98 \mathrm{X}_{1}-2.10 \mathrm{X}_{2}$; Equation 4: $\mathrm{Y}=93.27-0.99 \mathrm{X}_{1}-1.51 \mathrm{X}_{2}$; Equation 5: $\mathrm{Y}=113.92-1.02 \mathrm{X}_{1}-2.69 \mathrm{X}_{2}$; and Equation 6: $\mathrm{Y}=100.894+0.088 \mathrm{X}_{1}-4.084 \mathrm{X}_{2}$. For Equation 1, $\mathrm{Y}$ is the number of days to start sporulation in $50 \%$ of the lesions; $\mathrm{X}_{1}$ is the maximum average temperature, in degrees Fahrenheit; and $\mathrm{X}_{2}$ is the minimum average temperature, also in degrees Fahrenheit. For Equation 2, Y is the IP estimate, in days; and $\mathrm{X}$ is the average temperature, in Celsius. For Equations 3 to 6, under different cultivation conditions, $Y$ is the IP estimate, in days; $\mathrm{X}_{1}$ is the maximum average temperature, in Celsius; and $\mathrm{X}_{2}$ is the minimum average temperature, also in Celsius. 
Equations 3, 4, and 5 present a larger area in the medium and low classes. Summing both of these classes, Equation 3 covers $74.3 \%$ of the total area; Equation 4, 63.5\%; and Equation 5, 84.6\%. The amount of area in the very low severity class was $10 \%$, in alignment with the equations of Moraes et al. (1976). Only Equations 3 and 4 show data in the null severity class. Equation 4, compared with Equations 3 and 5, presents a $3.5 \%$ area in the very high class, for which the other equations showed no data (Figure $1 \mathrm{~A}$ ).

For Eta-MIROC5, the three equations by Moraes et al. (1976) did not present areas with an IP shorter than 29 days, suggesting medium to null severity in the study area. Equations 4 and 5 show a similar area in the low and very low classes, but Equation 4 presents a larger amount of area in the null class. Equation 5 has the highest amount of area of $57 \%$ in the low class; with the sum of the low and very low classes, the equation presents $85.7 \%$ of the total area in this IP range (Figure $1 \mathrm{~B}$ ).

In Eta-HadGEM2-ES, Equation 6 has the largest area in the most severe classes of coffee leaf rust: $45.8 \%$ with an IP between 0-19 days and 32.9\% in the high severity class (Figure 1 A). In Eta-MIROC5, Equation 6 shows the largest area reached by the medium and low severity classes (Figure $1 \mathrm{~B}$ ).

According to Alfonsi (2017), Eta-HadGEM2ES overestimates the temperature of the study area, while Eta-MIROC5 underestimates it. In a hotter climate condition, in Eta-HadGEM2-ES, the equation of Kushalappa \& Martins (1980) indicates a greater coffee leaf rust severity in relation to the other ones. However, Equation 5 seems to show a lower severity of the disease, probably because it was elaborated for shaded-coffee crops. In this condition, the temperature in the cultivation microclimate tends to be lower because of the shade of trees, indicating a lower severity of the disease when estimated by IP, for which temperature is the base element.

Equations 1 and 2 have the same time pattern (Figure $2 \mathrm{~A}, \mathrm{~B}, \mathrm{C}$, and D). It is possible to observe that, in the current scenario, the IP is shorter in the initial (January to June) and final (September to December) months of the year, indicating a higher degree of severity. The months with the shortest IP correspond to the hottest and rainiest season in the study area, with a greater severity in Eta-HadGEM2-ES (Figure $2 \mathrm{~A}$ and C), compared with Eta-MIROC5 (Figure 2 B and
D). In the Eta-HadGEM2-ES current scenario, only November shows a small area of $0.11 \%$ in the high severity class, with an IP between 0-19 days; with the exception of June and July, all months of the year have an IP shorter than 29 days. The future scenarios of both models increase the degree of severity and extend the short IPs throughout the months of the year. In the Eta-HadGEM2-ES future scenario (Figure $2 \mathrm{~A}$ and C), the hottest and rainiest months of the year (January, February, March, October, November, and December) increase, on average, $10.6 \%$ of the area in the very high class, and, in Eta-MIROC5, November is the month with the most pronounced increase, covering $19.7 \%$ of the area (Figure $2 \mathrm{~B}$ and $\mathrm{D}$ ).

Eta-MIROC5 predicts a lower severity, and its equations do not estimate IPs shorter than 19 days in any month of the year. Except for June and July, all months show an IP between 20-29 days, indicating an increase in the degree of severity and in the duration time of coffee leaf rust. From January to April and from August to December, the future scenario tends to be more severe than the current one, with approximately 17\% more area with an IP between 20 and 29 days. October is the month that, for both equations, has a pronounced $32 \%$ increase in the area with an IP between 20 and 29 days (Figure $2 \mathrm{~B}$ and D).

The temporal behavior of Equation 3 is shown under macroclimate conditions, in Eta-HadGEM2ES (Figure 2 E) and Eta-MIROC5 (Figure 2 F). For Eta-HadGEM2-ES, the very high and high classes occur at a higher intensity in the hottest and rainiest seasons, i.e., in the initial (January to April) and final (September to December) months of the year. In this model, in the current scenario, November is presents $4 \%$ of the total study area in the very high severity class. As verified for Equations 1 and 2, the estimate obtained by Equation 3 increases the degree of severity in the future scenario, increasing the amount of total affected area to $17.7 \%$, on average, for an IP shorter than 19 days and extending severity to months that had not previously registered a short IP. November is the month with the largest increase of $26.14 \%$ in the total area with an IP of 0-19 days. When analyzing the high severity class, with an IP between 20-29 days, April is the month that shows the largest area increase of $40.7 \%$ in the future scenario.

In Eta-MIROC5, Equation 3 does not present an area with an IP shorter than 29 days, indicating medium 


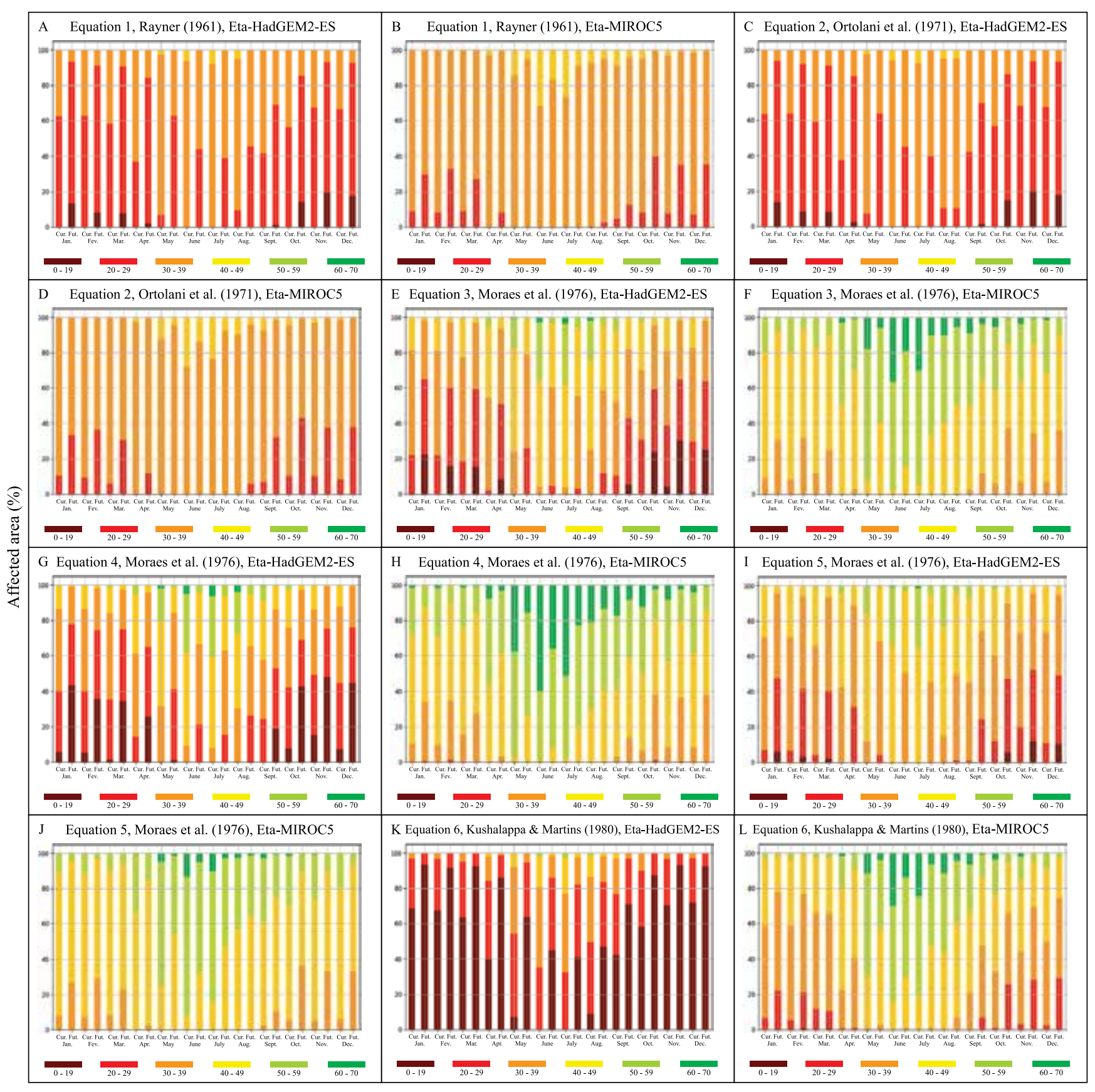

Incubation period (days)

Figure 2. Incubation period of coffee leaf rust (Hemileia vastatrix) in Arabica coffee (Coffea arabica) and affected area in the states of Minas Gerais and São Paulo, Brazil, according to the six used equations, for six severity classes, obtained by the Eta-HadGEM2-ES and Eta-MIROC5 regional models for current and future scenarios from 1960-1990 and from 2011-2040, respectively. Equation 1 ( $\mathrm{A}$ and $\mathrm{B}$ ): $\mathrm{Y}=90.61-0.408 \mathrm{X}_{1}-0.440 \mathrm{X}_{2}$; Equation 2 (C and D): $\mathrm{Y}=63.47-1.526 \mathrm{X}$; Equation $3(\mathrm{E}$ and $\mathrm{F})$ : $\mathrm{Y}=103.01-0.98 \mathrm{X}_{1}-2.10 \mathrm{X}_{2}$; Equation $4(\mathrm{G}$ and $\mathrm{H})$ : $\mathrm{Y}=93.27-0.99 \mathrm{X}_{1}-1.51 \mathrm{X}_{2}$; Equation 5 (I and $\left.\mathrm{J}\right)$ : $\mathrm{Y}=113.92-1.02 \mathrm{X}_{1}-2.69 \mathrm{X}_{2}$; and Equation $6(\mathrm{~K}$ and $\mathrm{L}): \mathrm{Y}=100.894+0.088 \mathrm{X}_{1}-4.084 \mathrm{X}_{2}$. For Equation $1, \mathrm{Y}$ is the number of days to start sporulation in $50 \%$ of the lesions; $\mathrm{X}_{1}$ is the maximum average temperature, in degrees Fahrenheit; and $\mathrm{X}_{2}$ is the minimum average temperature, also in degrees Fahrenheit. For Equation 2, $\mathrm{Y}$ is the IP estimate, in days; and $\mathrm{X}$ is the average temperature, in Celsius. For Equations 3 to 6, under different cultivation conditions, $\mathrm{Y}$ is the IP estimate, in days; $\mathrm{X}_{1}$ is the maximum average temperature, in Celsius; and $\mathrm{X}_{2}$ is the minimum average temperature, also in Celsius. 
to low coffee leaf rust severity throughout the year. However, even with an IP longer than 29 days, it is still possible to identify the standard curve of greater severity in the hottest and rainiest months of the year, when compared with the coolest and driest months (Figure $2 \mathrm{E}$ and $\mathrm{F}$ ).

Equations 4 and 5 follow the same pattern of temporal behavior of Equation 3, in both models (Figure $2 \mathrm{G}, \mathrm{H}$, and $\mathrm{J}$ ). However, Equation 4 tends to be more rigorous as to the degree of severity; in the Eta-HadGEM2-ES future scenario, this equation tends to show a larger area in the very high class, that is, with an IP shorter than 19 days (Figure $2 \mathrm{G}$ and $\mathrm{H}$ ). In the general average of all months, the area with a high degree of severity tends to increase by $21 \%$ using Equation 4 and by $3.22 \%$ using Equation 5. In Equation 4, December and January are the months with the largest area with an IP shorter than 19 days, and there is an average increase of $37.4 \%$ in the study area. In Equation 5, the largest increase in the total area is of $11.8 \%$ in November, followed by $10.4 \%$ in December (Figure 2 G, H, I, and J).

In both scenarios, the equations of Eta-MIROC5 do not show degrees of severity below an IP of 29 days, following the general pattern, where low to null severity classes are observed in the coldest and driest months of the year (Figure $2 \mathrm{G}, \mathrm{H}, \mathrm{I}$, and J).

For Eta-HadGEM2-ES, Equation 6 shows the highest degree of severity throughout the months (Figure $2 \mathrm{~K}$ ). January to May and August to December present, on average, $49.7 \%$ of the total study area with an IP shorter than 19 days, which is an indicative of a very high severity of the disease. In the future scenario, there is tendency for an increase of $33.8 \%$ in the total area in the high severity class, and severity is extended to all months of the year. The increase in the study area ranges from $40 \%$ for July to $93 \%$ for November and January; i.e., the area with an IP shorter than 19 days increases more than $90 \%$ in November, December, January, February, and March (Figure $2 \mathrm{~K}$ ). For EtaMIROC5, the disease tends to be less severe over the months, but is also extended in relation to the current scenario (Figure 2 L).

The seasonal increase in the intensity and severity of the disease, which extends to months when it was not recorded, is important for preventive measures for the management and control of coffee leaf rust. In future scenarios of climate change, in situations where temperature tends to be higher than the current one, studies on management strategies and alternatives for the control of the disease will be necessary.

The scenarios based on the two regional climate models evaluated pointed to changes in the potential for occurrence of coffee leaf rust (Figure 3). There was a change in the behavior of the severity classes in the Eta-HadGEM2-ES and Eta-MIROC5 models, comparing current and future scenarios with the set of six equations used (Figure 4). It is possible to verify that Eta-HadGEM2-ES increases the area in the very high and high classes in a larger proportion than EtaMIROC5. In the future scenario, the total study area in the very high severity class and with an IP shorter than 19 days tends to increase in $14.2 \%$ by Eta-HadGEM2ES, but in less than $0.5 \%$ by Eta-MIROC5. In this same scenario, the high severity class, with an IP between 20 and 29 days, increases in 13.4\% when predicted by Eta-HadGEM2-ES, while the other severity classes (medium, low, very low, and null) show a reduction of $10.9,11.8,4.5$, and $0.04 \%$, respectively (Table 2 ). Therefore, for the future scenario of high greenhouse gas emissions obtained by Eta-HadGEM2-ES, the sum of the very high and high classes can increase in $27.58 \%$ the total study area, indicating a higher probability of the occurrence of coffee leaf rust in the states of São Paulo and Minas Gerais.

Similar results were found by Ghini et al. (2011b) when predicting the effects of climate change on coffee leaf rust, using three global climate models - CSIROMk3.0, INM-CM3.0, and MIROC3.2.medres -, based on the fourth report of IPCC (Solomon et al., 2007). The authors compared the climate normal data from 1961-1990 with future data from the 2020's, 2050's, and 2080's, concluding that there was a tendency of a decrease in the IP and of an increase in the degree of coffee leaf rust severity. Hamada et al. (2015), using 15 global climate models, also concluded that there is a tendency of increase in coffee leaf rust over the years in the Southeastern region of Brazil.

In the Eta-MIROC5 future scenario, the high severity class increases the most, $6.8 \%$ compared with the total study area. The medium and low severity classes increase in 3.8 and $0.07 \%$, respectively. However, the very low and null classes tend to decrease in 6.8 and $3.8 \%$, respectively (Table 2 ). These results suggest that Eta-MIROC5 estimates a longer IP for the future scenario, indicating a lower probability of higher levels 


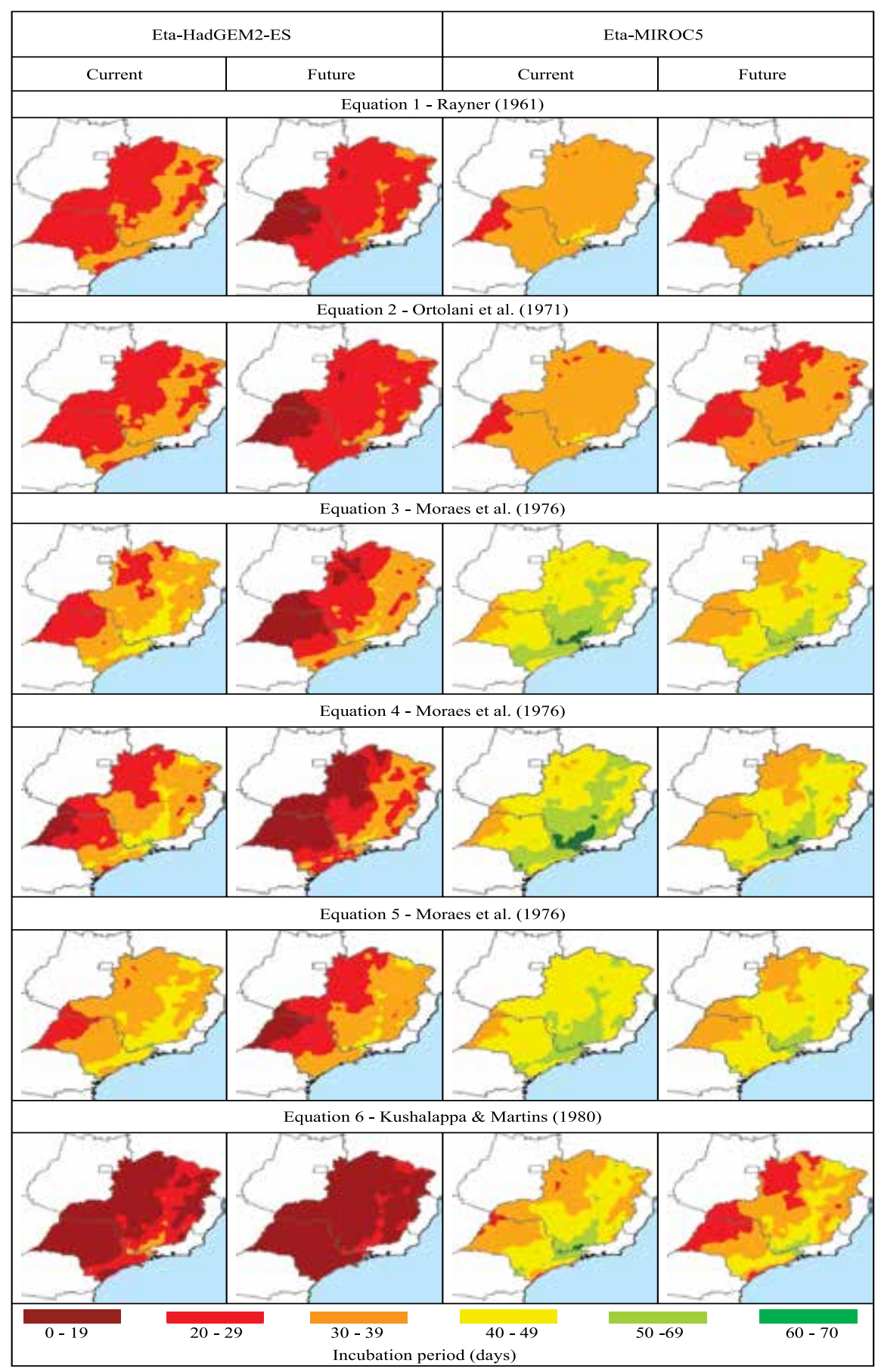

Figure 3. Incubation period of coffee leaf rust (Hemileia vastatrix) in Arabica coffee (Coffea arabica), in the states of Minas Gerais and São Paulo, Brazil, according to equations 1 to 6, for current and future climate scenarios from 1961-1990 and 2011-2040, respectively, in December, obtained by the Eta-HadGEM2-ES and Eta-MIROC5 regional models. Equation 1: Y $=90.61-0.408 \mathrm{X}_{1}-0.440 \mathrm{X}_{2} ;$ Equation 2: $\mathrm{Y}=63.47-1.526 \mathrm{X}$; Equation 3: $\mathrm{Y}=103.01-0.98 \mathrm{X}_{1}-2.10 \mathrm{X}_{2}$; Equation 4: $\mathrm{Y}=93.27$ - $0.99 \mathrm{X}_{1}-1.51 \mathrm{X}_{2}$; Equation 5: $\mathrm{Y}=113.92-1.02 \mathrm{X}_{1}-2.69 \mathrm{X}_{2}$; and Equation 6: $\mathrm{Y}=100.894+0.088 \mathrm{X}_{1}-4.084 \mathrm{X}_{2}$. For Equation $1, \mathrm{Y}$ is the number of days to start sporulation in $50 \%$ of the lesions; $\mathrm{X}_{1}$ is the maximum average temperature, in degrees Fahrenheit; and $\mathrm{X}_{2}$ is the minimum average temperature, also in degrees Fahrenheit. For Equation 2, $\mathrm{Y}$ is the IP estimate, in days; and $\mathrm{X}$ is the average temperature, in Celsius. For Equations 3 to 6, under different cultivation conditions, $\mathrm{Y}$ is the IP estimate, in days; $\mathrm{X}_{1}$ is the maximum average temperature, in Celsius; and $\mathrm{X}_{2}$ is the minimum average temperature, also in Celsius. 
of severity of coffee leaf rust, which is in alignment with Hamada et al. (2011). When studying diseases on vine using global models from the fourth report of
IPCC (Solomon et al., 2007), these authors concluded that, in the future scenario, there is the probability of a reduction in the favorable area for vine diseases.

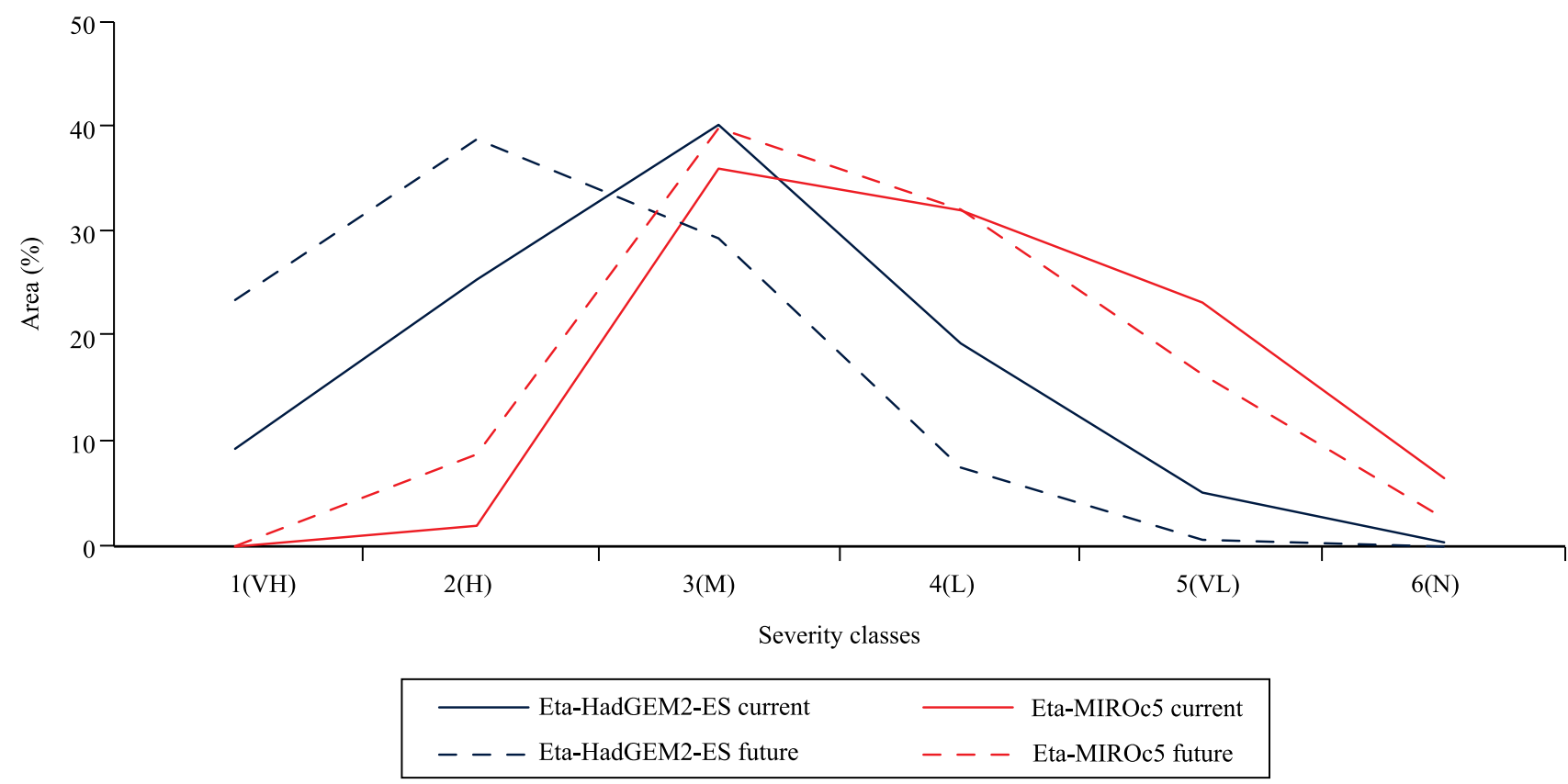

Figure 4. Study area (mean percentage) for each class of coffee leaf rust (Hemileia vastatrix) severity in Arabica coffee (Coffea arabica), in the states of Minas Gerais and São Paulo, Brazil, for the Eta-HadGEM2-ES (blue line) and EtaMIROC5 (red line) regional models, in current (solid line) and future (dotted line) scenarios from 1961-1990 and 2011-2040, respectively. Severity classes: 1(VH), very high; 2(H), high; 3(M), medium; 4(L), low; 5(VL), very low; and 6(N), null.

Table 2. Area in each class of degree of coffee leaf rust (Hemileia vastatrix) severity in Arabica coffee (Coffea arabica) for the used set of equations ${ }^{(1)}$ and difference between current and future scenarios, obtained by the Eta-HadGEM2-ES and Eta-MIROC5 regional models.

\begin{tabular}{|c|c|c|c|c|c|c|}
\hline \multirow[t]{2}{*}{ Class } & \multicolumn{3}{|c|}{ Eta-HadGEM2-ES } & \multicolumn{3}{|c|}{ Eta-MIROC5 } \\
\hline & $\begin{array}{c}\text { Total of current } \\
\text { area }(\%)\end{array}$ & $\begin{array}{l}\text { Total of future } \\
\text { area }(\%)\end{array}$ & Difference & $\begin{array}{c}\text { Total of current area } \\
(\%)\end{array}$ & $\begin{array}{c}\text { Total of future } \\
\text { area }(\%)\end{array}$ & Difference \\
\hline 1. Very high & 9.32 & 23.52 & 14.20 & 0.01 & 0.02 & 0.01 \\
\hline 2. High & 25.49 & 38.88 & 13.39 & 2.00 & 8.79 & 6.79 \\
\hline 3. Medium & 40.26 & 29.41 & -10.85 & 36.09 & 39.94 & 3.84 \\
\hline 4. Low & 19.37 & 7.56 & -11.81 & 32.09 & 32.17 & 0.07 \\
\hline 5. Very low & 5.14 & 0.62 & -4.52 & 23.29 & 16.42 & -6.87 \\
\hline 6. Null & 0.41 & 0.00 & -0.40 & 6.51 & 2.67 & -3.84 \\
\hline
\end{tabular}

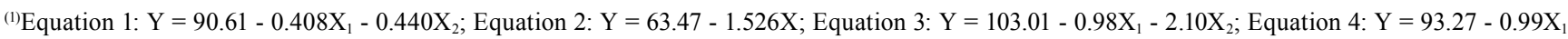
- $1.51 \mathrm{X}_{2}$; Equation 5: $\mathrm{Y}=113.92-1.02 \mathrm{X}_{1}-2.69 \mathrm{X}_{2}$; and Equation 6: $\mathrm{Y}=100.894+0.088 \mathrm{X}_{1}-4.084 \mathrm{X}_{2}$. For Equation 1, $\mathrm{Y}$ is the number of days to start sporulation in $50 \%$ of the lesions; $\mathrm{X}_{1}$ is the maximum average temperature, in degrees Fahrenheit; and $\mathrm{X}_{2}$ is the minimum average temperature, also in degrees Fahrenheit. For Equation 2, $\mathrm{Y}$ is the IP estimate, in days; and $\mathrm{X}$ is the average temperature, in Celsius. For Equations 3 to 6, under different cultivation conditions, $\mathrm{Y}$ is the IP estimate, in days; $\mathrm{X}_{1}$ is the maximum average temperature, in Celsius; and $\mathrm{X}_{2}$ is the minimum average temperature, also in Celsius. 


\section{Conclusions}

1. The future scenarios predicted by the EtaHadGEM2-ES and Eta-MIROC5 regional models project an increase of 0.5 to $14.2 \%$, respectively, in coffee leaf rust in Arabica coffee (Coffea arabica) in the states of São Paulo and Minas Gerais, Brazil, with incubation periods of less than 19 days, that is, a very high severity of the disease.

2. The Eta-HadGEM2-ES model shows a greater expansion potential of the very high coffee leaf rust severity class with an incubation period equal to or shorter than 19 days, in most of the states of São Paulo and Minas Gerais.

3. There is a tendency of a seasonal increase in the incubation period, i.e., months that presented low severity classes for incubation periods above 40 days will show higher severity classes for incubation periods below 40 days, increasing the probability of more severe coffee leaf rust epidemics.

4. Temporal variability follows the dynamics of the infection potential, also decreasing in winter months and increasing in the rainiest and hottest months of the year.

5. In the scenarios predicted by Eta-HadGEM2ES and Eta-MIROC5, the equation of Kushalappa \& Martins shows the highest decrease in the incubation period and the highest potential for rust severity.

\section{Acknowledgments}

To Conselho Nacional de Desenvolvimento Científico e Tecnológico (CNPq), for scholarship; to Faculdade de Engenharia Agrícola (Feagri) and to Centro de Pesquisas Meteorológicas e Climáticas Aplicadas à Agricultura(Cepagri), both of Universidade Estadual de Campinas (Unicamp), for the opportunity to perform this research; and to Instituto Nacional de Pesquisas Espaciais (Inpe) and to Fundação Procafé, for providing the essential data for this work.

\section{References}

ALFONSI, W.M.V. Vulnerabilidade do cafeeiro arábica à ferrugem (Hemileia vastatrix) em cenários de mudanças climáticas. 2017. 176p. Tese (Doutorado) - Universidade Estadual de Campinas, Campinas.

ASSAD, E.D.; PINTO, H.S.; ZULLO UNIOR, J.; ÁVILA, A.M.H. Impacto das mudanças climáticas no zoneamento agroclimático do café no Brasil. Pesquisa Agropecuária
Brasileira, v.39, p.1057-1064, 2004. DOI: https://doi.org/10.1590/ S0100-204X2004001100001.

AVELINO, J.; CRISTANCHO, M.; GEORGIOU, S.; IMBACH, P.; AGUILAR, L.; BORNEMANN, G.; LÄDERACH, P.; ANZUETO, F.; HRUSKA, A.J.; MORALES, C. The coffee rust crises in Colombia and Central America (2008-2013): impacts, plausible causes and proposed solutions. Food Security, v.7, p.303-321, 2015. DOI: https://doi.org/10.1007/s12571-015-0446-9.

CHAKRABORTY, S.; TIEDEMANN, A.V.; TENG, P.S. Climate change: potential impact on plant diseases. Environmental Pollution, v.108, p.317-326, 2000. DOI: https://doi.org/10.1016/ S0269-7491(99)00210-9.

CHOU, S.C.; LYRA, A.; MOURÃO, C.; DERECZYNSKI, C.; PILOTTO, I.; GOMES, J.; BUSTAMANTE, J.; TAVARES, P.; SILVA, A.; RODRIGUES, D.; CAMPOS, D.; CHAGAS, D.; SUEIRO, G.; SIQUEIRA, G.; MARENGO, J. Assessment of climate change over South America under RCP 4.5 and 8.5 downscaling scenarios. American Journal of Climate Change, v.3, p.512-525, 2014. DOI: https://doi.org/10.4236/ajcc.2014.35043.

FRIEDLINGSTEIN， P.; ANDREW， R.M.; ROGELJ, J.; PETERS, G.P.; CANADELL, J.G.; KNUTTI, R.; LUDERER, G.; RAUPACH, M.R.; SCHAEFFER, M.; VAN VUUREN, D.P.; LE QUÉRÉ, C. Persistent growth of $\mathrm{CO}_{2}$ emissions and implications for reaching climate targets. Nature Geoscience, v.7, p.709-715, 2014. DOI: https://doi.org/10.1038/ngeo2248.

GAY, C.; ESTRADA, F.; CONDE, C.; EAKIN, H.; VILLERS, L. Potential impacts of climate change on agriculture: a case of study of coffee production in Veracruz, Mexico. Climatic Change, v.79, p.259-288, 2006. DOI: https://doi.org/10.1007/s10584-0069066-x.

GHINI, R.; BETTIOL, W.; HAMADA, E. Diseases in tropical and plantation crops as affected by climate changes: current knowledge and perspectives. Plant Pathology, v.60, p.122-132, 2011a. DOI: https://doi.org/10.1111/j.1365-3059.2010.02403.x.

GHINI, R.; HAMADA, E.; PEDRO JÚNIOR, M.J.; GONÇALVES, R.R. do V. Incubation period of Hemileia vastatrix in coffee plants in Brazil simulated under climate change. Summa Phytopathologica, v.37, p.85-93, 2011b. DOI: https://doi.org/10.1590/S0100-54052011000200001.

GHINI, R.; HAMADA, E.; PEDRO JÚNIOR, M.J.; MARENGO, J.A.; GONÇALVES, R.R. do V. Risk analysis of climate change on coffee nematodes and leaf miner in Brazil. Pesquisa Agropecuária Brasileira, v.43, p.187-194, 2008. DOI: https://doi.org/10.1590/S0100-204X2008000200005.

HAMADA, E.; GHINI, R.; GONÇALVES, R.R. do V. Efeito da mudança climática sobre problemas fitossanitários de plantas: metodologia de elaboração de mapas. Engenharia Ambiental, v.3, p.73-85, 2006.

HAMADA, E.; GHINI, R.; MARENGO, J.A.; THOMAZ, M.C. Projeções de mudanças climáticas para o Brasil no final do século XXI. In: GHINI, R.; HAMADA, E.; BETTIOL, W. (Ed.). Impactos das mudanças climáticas sobre doenças de importantes culturas no Brasil. Jaguariúna: Embrapa Meio Ambiente, 2011. p.41-74. 
HAMADA, E.; VOLPATO, M.M.L.; FERREIRA, G. de L.; ALVES, H.M.R.; SOUZA, V.C.O. de; VIEIRA, T.G.C. Simulação dos efeitos das mudanças climáticas sobre a ferrugem do café na região Sudeste do Brasil. In: SIMPÓSIO BRASILEIRO DE SENSORIAMENTO REMOTO, 17., 2015, João Pessoa. Anais. São José dos Campos: INPE, 2015. p.2629-2636.

JARAMILlO, J.; MUCHUGU, E.; VEGA, F.E.; DAVIS, A.; BORGEMEISTER, C.; CHABI-OLAYE, A. Some like it hot: the influence and implications of climate change on coffee berry borer (Hypothenemus hampei) and coffee production in east Africa. PLoS ONE, v.6, e24528, 2011. DOI: https://doi.org/10.1371/ journal.pone.0024528.

KUSHALAPPA, A.C.; MARTINS, C.P. Incubation periods for Hemileia vastatrix on coffee in Viçosa, Minas Gerais. Fitopatologia Brasileira, v.6, p.177-183, 1980.

LÓPEZ-BRAVO, D.F.; VIRGINIO-FILHO, E. de M.; AVELINO, J. Shade is conducive to coffee rust as compared to full sun exposure under standardized fruit load conditions. Crop Protection, v.38, p.21-29, 2012. DOI: https://doi.org/10.1016/j. cropro.2012.03.011.

MEIRA, C.A.A.; RODRIGUES, L.H.A.; MORAES, S.A. de. Modelos de alerta para o controle da ferrugem-do-cafeeiro em lavouras com alta carga pendente. Pesquisa Agropecuária Brasileira, v.44, p.233-242, 2009. DOI: https://doi.org /10.1590/ S0100-204X2009000300003.

MORAES, S.A.; SUGIMORI, M.H.; RIBEIRO, I.J.A.; ORTOLANI, A.A.; PEDRO JR., M.J. Período de incubação de Hemileia vastatrix Berk. et Br. em três regiões do estado de São Paulo. Summa Phytopathologica, v.2, p.32-38, 1976.

ORTOLANI, A.A.; VIANA, A.C.C.; ABREU, R.G. de. Hemileia vastatrix Berk et Br. estudos e observações em regiões da África e sugestões a cafeicultura do Brasil. Rio de Janeiro: IBC-GERCA, 1971. 193p. Relatório de missão realizada em Angola, África do Sul, Quênia, Tanzânia, Uganda e instituições de pesquisa em relação à ferrugem do cafeeiro.

OVALLE-RIVERA， O.; LÄDERACH， P.; BUNN， C.; OBERSTEINER, M.; SCHROTH, G. Projected shifts in Coffea arabica suitability among major global producing regions due to climate change. PLoS ONE, v.10, e0124155, 2015. DOI: https://doi.org/10.1371/journal.pone.0124155.

PATRÍCIO, F.R.A. Efeito das mudanças climáticas sobre a ferrugem do cafeeiro. In: BETTIOL, W.; HAMADA, E.; ANGELOTTI, F.; AUAD, A.M.; GHINI, R. (Ed.). Aquecimento global e problemas fitossanitários. Brasília: Embrapa, 2017. p.204-220.

RAUPACH, M.R.; DAVIS, S.J.; PETERS, G.P.; ANDREW, R.M.; CANADELL, J.G.; CIAIS, P.; FRIEDLINGSTEIN, P.; JOTZO, F.; Van VUUREN, D.P.; LE QUÉRÉ, C. Sharing a quota on cumulative carbon emissions. Nature Climate Change, v.4, p.873-879, 2014. DOI: https://doi.org/10.1038/nclimate2384.

RAYNER, R.W. Germination and penetration studies on coffee rust (Hemileia vastatrix B. \& Br.). Annals of Applied Biology, v.49, p.497-505, 1961. DOI: https://doi.org/10.1111/j.1744-7348.1961. tb03641.x.

SEEM, R.C. Forecasting plant disease in a changing climate: a questionofscale.CanadianJournalofPlantPathology,v.26,p.274283, 2004. DOI: https://doi.org/10.1080/07060660409507144.

SOLOMON, S.; QIN, D.; MANNING, M.; MARQUIS, M.; AVERYT, K.; TIGNOR, M.M.B.; MILLER JR., H.L.; CHEN, Z. (Ed.). Climate Change 2007: the physical science basis. Cambridge: Cambridge University Press, 2007. 996p. Contribution of Working Group I to the Fourth Assessment Report of the Intergovernmental Panel on Climate Change. IPCC.

TAVARES, P. da S.; GIAROLLA, A.; CHOU, S.C.; SILVA, A.J. de P.; LYRA, A. de A. Climate change impact on the potential yield of Arabica coffee in southeast Brazil. Regional Environmental Change, v.18, p.873-883, 2017. DOI: https://doi.org/10.1007/ s10113-017-1236-z.

VILLERS, L.; ARIZPE, N.; ORELLANA, R.; CONDE, C.; HERNÁNDEZ, J. Impactos del cambio climático en la floración y desarrollo del fruto del café en Veracruz, México. Interciencia, v.34, p.322-329, 2009.

WALlis, J.A.N. A ferrugem do cafeeiro na América do Sul. Londres, 1970. 52p. Relatório apresentado a Organização Mundial do Café.

ZAMBOLIM, L. Current status and management of coffee leaf rust in Brazil. Tropical Plant Pathology, v.41, p.1-8, 2016. DOI: https://doi.org/10.1007/s40858-016-0065-9.

ZULLO JR., J.; PINTO, H.S.; ASSAD, E.D.; ÁVILA, A.M.H. de. Potential for growing Arabica coffee in the extreme south of Brazil in a warmer world. Climatic Change, v.109, p.535-548, 2011. DOI: https://doi.org/10.1007/s10584-011-0058-0.

ZULLO JUNIOR, J.; PINTO, H.S.; ASSAD, E.D. Impact assessment study of climate change on agricultural zoning. Meteorological Applications, v.13, p.69-80, 2006. Supplement. DOI: https://doi.org/10.1017/S135048270600257X. 